\title{
TOWARDS SUSTAINABLE DOWNY MILDEW RESISTANCE IN SUNFLOWER
}

Jocić, S. , Miladinović, D., Imerovski, I., Dimitrijević, A., Cvejić, S., Nagl, N., Kondić-Špika, A.

Institute of Field and Vegetable Crops, Maksima Gorkog 30, 21000 Novi Sad, Republic of Serbia

\author{
SUMMARY
}

Breeding for downy mildew resistance is one of the major goals in sunflower breeding programmes. In the last few decades new sources of resistance have been discovered and the position of 11 resistance genes was established on the genetic map of sunflower. For most of these resistance genes sequence specific markers have been developed, which facilitate their detection and make the selection process faster and more reliable. By combining the partial resistance provided by minor genes with specific resistance genes, durable resistance could be achieved.

\section{Key words: sunflower, downy mildew, resistance, molecular markers, breeding}

\section{INTRODUCTION}

Downy mildew is a sunflower disease caused by Plasmopara halstedii (Farl.) Berlese et de Toni, an oomycete with high virulence, aggressiveness and a great potential in developing new races.

Downy mildew infection can be primary (soilborne and seedborne) and secondary (airborne) (Aćimović, 1998). Primary infection causes more severe symptoms and a decay of a plant, while secondary infection usually results in small angular spots on leaves without limiting the sunflower yield (Jocić et al., 2009). Under humid conditions, oospores germinate into zoosporangia, which liberate flagellate zoospores. Spores move towards the roots and penetrate into the tissue, thereby initiating primary infection (Delanoe, 1971, according to Viranyi and Spring, 2011). Infected plants tend to be insufficiently developed, dwarfed, with chlorotic leaves covered with white mycelium (Dussle et al., 2004).

Extent of the damage that the pathogen causes is influenced by several factors:

* Corresponding author: e-mail: sinisa.jocic@ifvcns.ns.ac.rs 
1) environmental conditions, primarily humidity and temperature (Wehtje and Zimmer, 1978; Aegerter, 2003; Tourvieille de Labrouhe et al., 2008b);

2) potential of pathogen for host inoculation, i.e., zoosporangia viability (Meliala et al., 2000; Tourvieille de Labrouhe et al., 2000) and,

3) genetic resistance or susceptibility of the crop.

Efficient control of downy mildew requires an understanding of the pathogen's fundamental biology, molecular mechanism of infection, development and reproduction (Sakr et al., 2009; Sakr et al., 2010), as well as identification and determination of position and function of the host resistance genes.

\section{Population dynamics and molecular characterization of the pathogen}

Until 1980, only two races of downy mildew were known. After the races from the USA came in contact with the races from Europe, a number of races emerged in different parts of the world. Until the present day, 14 races of downy mildew have been identified in Europe (Delmotte et al., 2008) and 35 worldwide (Gulya et al., 1991; Gulya, 2007). In France, race 100 was the solely present from 1965 until 1987.

Zimmer and Fick (1974) found that gene $P l_{1}$ provides resistance against race 100 and $\mathrm{Pl}_{2}$ against races 100 and 300. These two genes controlled the downy mildew population in Europe until 1998 when new races emerged (710 and 703) in France (Tourvieille de Labrouhe et al., 1991; Tourvieille de Labrouhe et al., 2000; Delmotte et al., 2008). Later research showed that these races were introduced from the USA via infected seeds (Roeckel-Drevet et al., 2003). Afterwards, a number of highly aggressive races, e.g., 304, 307, 314, 334, 704 and 714, evolved (Tourvieille de Labrouhe et al., 2000; Sakr, 2010). In Serbia, race 100 was the only race until 1990. In 1991, the presence of race 730 was confirmed (Maširević, 1998), and it soon became the prevailing race in the country (Lačok, 2008).

Division on races is based on the reaction of an internationally accepted set of differential lines to the pathogen (Tourvieille de Labrouhe et al., 2000). In the last decade advanced tools of biotechnology have enabled discernment of intraspecific groups of Plasmopara on molecular level and led to the shift from a morphological to a phylogenetic species concept (Spring and Thines, 2004). With molecular markers based on partial sequence of the nuclear ITS regions, Spring et al. (2006) detected polymorphism between profiles of races 100,310 and 330 , as well as between groups of populations representing races 700, 701, 703, 710 and 730 . Giress et al. (2007) found high genetic variability between the isolates from France and Russia using SNP markers, whereas Sakr (2010) utilized EST - derived markers to determine genetic relationship between the races. Interestingly, new insights from molecular phylogenetics often verify a narrow species concept that was proposed by Gäumann in 1918 (Voglmayr and Constantinescu, 2008).

\section{Disease-control measures}

The disease control measures could be divided in:

- agrotechnical,

- chemical and

- breeding for resistance. 
1) Agrotechnical measures include a proper crop rotation and use of healthy seed treated with fungicides. The recommended cultivation practices include: the use of healthy seeds for planting; coating of the seeds with fungicides against downy mildew; proper crop rotation, i.e., maintaining intervals of 4-5 years between two sunflower cultivation in the same field; selecting fields that are at least $500 \mathrm{~m}$ away from a field on which sunflower was grown the previous year. Since the infected harvest remains in that field, volunteer plants should be removed from the field and deep plowing of the field should be done after the sunflower harvest. Additionally, sowing should be performed at optimum time, with the avoidance of late planting (Jocić et al., 2010).

2) Today a wide range of commercial fungicides are available on the market (Gisi, 2002) with different modes of action (Gisi and Sierotzki, 2008). Coating of seeds with metalaxyle derivates is most frequently used, as it provides protection at the time of the primary infection, i.e., at early stages of development of sunflower. Concerning issues related to the use of chemical control include emerging of races resistant to the fungicide in France, Germany, Turkey and Hungary (Viranyi and Spring, 2011), negative environmental effects of the fungicides as well as the economic feasibility of this disease control measure.

3) Resistance genes, denoted $\mathrm{Pl}$ genes, provide complete resistance to pathogen. From 1978 on, commercial varieties in France have always carried one or more $P l$ genes (Miller and Gulya, 1988; Vear et al., 2008). As the $P l$ genes are race-specific, there is a great probability that new races of downy mildew will overcome them in a relatively short period of time. Even though monogenic resistance is not durable, introgression of $P l$ genes is still among the most efficient methods of controlling downy mildew.

4) Induced resistance (often called systemic or acquired resistance) implies the use of specific chemical compounds for triggering plants defence mechanisms (Mauch-Mani, 2002; Korosi et al., 2011). This method, which was developed in the last few decades (Mauch-Mani, 2002), has been proven to be efficient in diminishing the severity of infection in genotypes without genetic resistance (Gisi, 2002).

The frequency of resistant pathogen individuals often starts increasing after the intensive use of an effective method. While controlling the sensitive pathogen subpopulations, disease-control measures enable progress of the resistant subpopulations, which soon become dominant. In order to prolong resistance duration, several control measures need to be applied simultaneously. As far as genetic resistance is concerned, durable resistance could be achieved by combining quantitative with monogenic resistance (Vear et al., 2008), or by introducing genes from different clusters and with different origin in a single genotype (Jocić et al., 2010). 


\section{Genetic resistance of sunflower to downy mildew}

Genetic resistance can be classified into two categories:

1) partial resistance which is controlled by minor genes (QTLs), and tends to influence the extent of disease development (Tourvieille de Labrouhe et al., 2008a) and,

2) qualitative or monogenic resistance, conferred by the $P l$ genes.

\section{Partial resistance controlled by minor genes}

Partial resistance, also called field, general, quantitative or horizontal resistance, is usually not race-specific and is assumed to be polygenic. The use of partial resistances does not appear to have as strong effect on pathogen populations as the monogenic resistance. By combining the partial resistance provided by minor genes with specific resistance genes, durable resistance could be achieved (Tourvieille de Labrouhe et al., 2008a). It has been shown that QTLs provide tolerance to a number of pathogens such as Sclerotinia sclerotiorum (Vasić et al., 2004), Diaporthe helianthi (Mihaljčević et al., 1982; Škorić 1985), Phoma macdonaldii (Vear et al., 2008), and Orobanche cumana (Pérez-Vich et al., 2004). Rachid AlChaarani et al. (2002) found four putative QTLs. The three major QTLs were located on LG 1, 9 and 17, and explained $54.9 \%$ of the total phenotypic variance. Vear et al. (2008) reported two QTL located on LG 10 and LG 8, and suggested microsatellite markers ORS613 and ORS389 for their detection.

\section{Qualitative or monogenic resistance}

The outcome of the infection is predetermined by genetic constitution of the host. Sunflower and downy mildew have a typical "gene-for-gene relationship" - for each virulence gene presented in the pathogen exists a corresponding resistance gene in the host plant. If the plant has an effective resistance gene that will counteract the virulence gene in the pathogen, the infection will be stopped near the penetration site. Cotyledon limited infection (CLI, Gulya et al., 1991) is a phenomenon observed in resistant genotypes. It is caused by hypersensitive reaction (HR) that is manifested as an extensive cell death in the tissue of infected hypocotyls (Mouzeyar et al., 1993; 1994). Molecular mechanisms of HR include activation of glutationperoxidase gene (Herbette et al., 2003) and hsr230J-like gene (Radwan et al., 2005). When the cascade is activated, a number of linked processes occur in the apoptotic cells - respiration rates increase, production of nitric oxide (NO) and reactive oxygen species (ROS) elevates, leading to an oxidative burst. As a result, invading pathogen cells are neutralized.

Genes that confer resistance to downy mildew are dominant and often form clusters. Until the present day a number of $P l$ genes have been reported $\left(P l_{1-15}, P l_{v}\right.$, $P l_{w}, P l_{x-Z}, M_{w}, M_{x}, P l_{\text {arg }}, P l_{H A-R 4}$ ) (Table 1), and position of 11 genes has been determined on the SSR genetic map (Figures 1 and 2). It is usually the case that new resistance genes provide resistance to earlier races of the pathogen. 


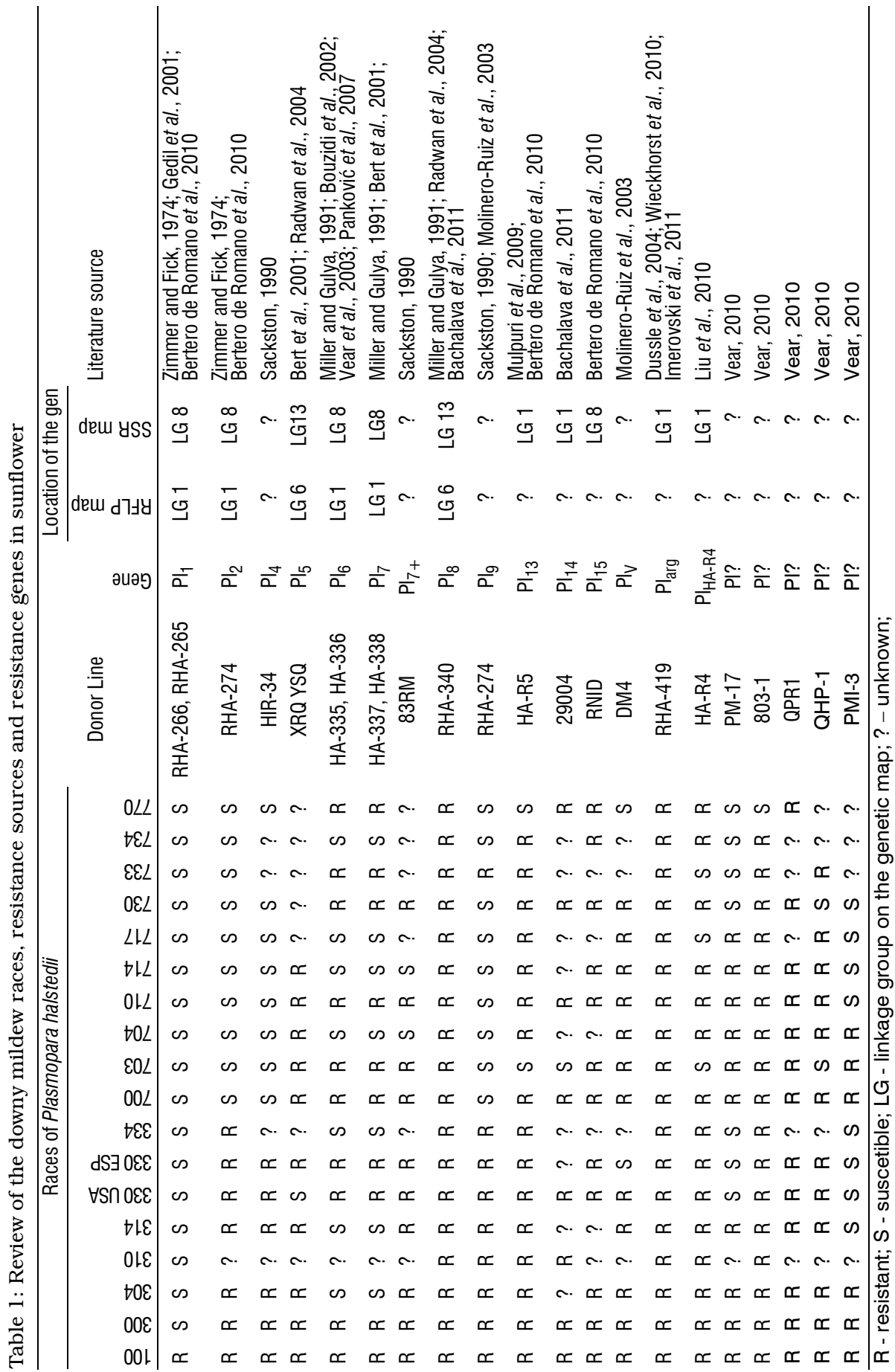


Resistance genes are often found in wild sunflower species. Inbred lines have been developed from these wild species, which are then used as donors of resistance genes. Thus, $\mathrm{Pl}_{6}$ was introduced from wild ecotype of $H$. annuus (Miller and Gulya, 1991), $\mathrm{Pl}_{5}$ from $\mathrm{H}$. tuberosus (Vranceanu et al., 1981), $\mathrm{Pl}_{7}$ from $\mathrm{H}$. praecox (Miller and Gulya, 1991), and $\mathrm{Pl}_{8}$ and $\mathrm{Pl}_{\text {arg }}$ from $\mathrm{H}$. argophyllus (Miller and Gulya, 1991; Seiler et al., 1991). Along with resistance genes, lines developed from wild sunflower species also inherit a number of undesirable characteristics. When the donor lines are used in commercial breeding programs they have to be crossed with inbred lines which have desirable agronomical traits (Jocić et al., 2010).

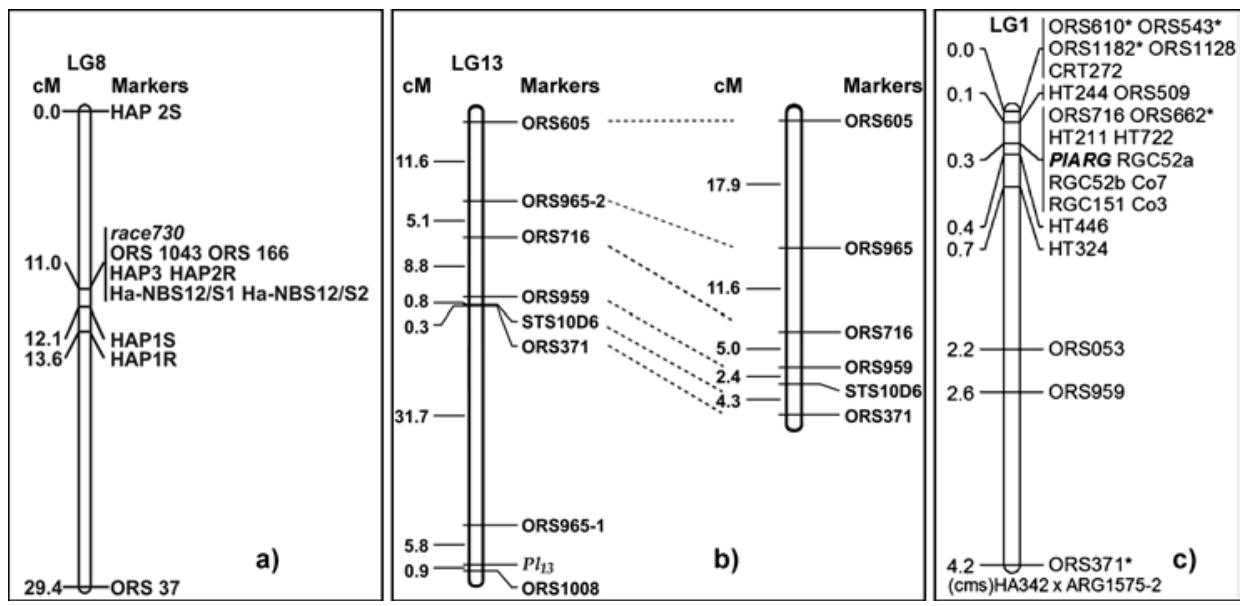

Figure 1: Location of some of the Pl genes on genetic maps: a) position of the $\mathrm{Pl}_{6}$ on LG8 (Panković et al., 2007), b) position of the $\mathrm{Pl}_{13}$ on LG 13 (Mulpuri et al., 2009), c) position of the $P l_{\text {arg }}$ on LG1 (Dussle et al., 2004)

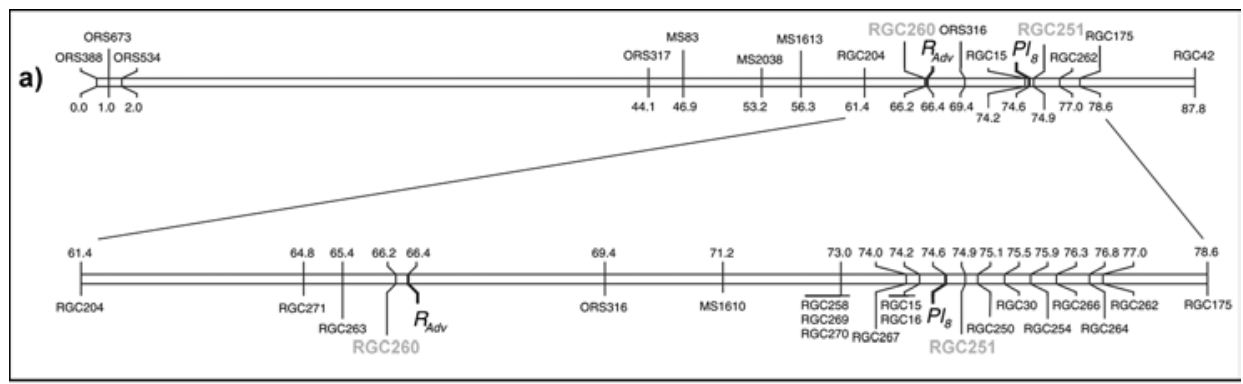

b)

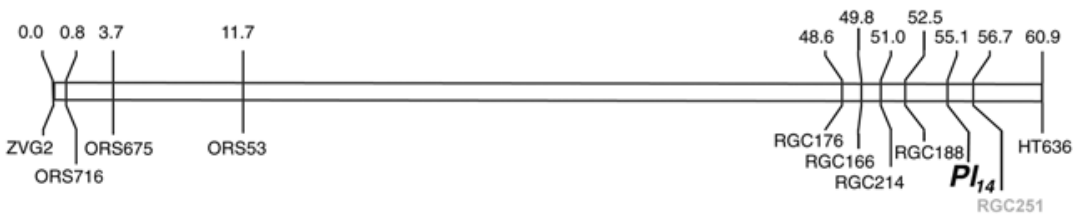

Figure 2: Position of the genes $\mathrm{Pl}_{14}\left(\right.$ a) and $\mathrm{Pl}_{8}(b)$ (Bachalava et al., 2010). 
Molecular markers have become a valuable tool in breeding programs (Kaya et al., 2012). Molecular techniques, such as RFLP, SSR, INDEL, TRAP and SNP markers, enabled construction of genetic maps (Gentzbittel et al., 1995; Yu et al., 2002; Tang et al., 2002; Yu et al., 2003; Lai et al., 2005) that greatly facilitated mapping of $P l$ genes. The position of most of the $P l$ genes is known.

Molecular markers facilitate detection of $P l$ genes, make breeding faster and more reliable, and are becoming an essential part of selection process (Imerovski et al., 2011b; Miladinović et al., 2011).

\section{The link between the resistance genes and molecular markers}

Cloning of resistance genes gave a better understanding of their structure, and provided a key for their classification (Gentzbittel et al., 1998). Nearly three-fourths of the $R$-genes identified in plants encode nucleotide binding site (NBS) leucine-rich repeat (LRR) proteins (Radwan et al., 2008). NBS-LRR encoding genes are highly duplicated in genomes of all known plants and are arranged as large multi-gene clusters. Hundreds of NBS-LRR encoding genes have been identified in sequenced genomes. Assuming that similar genes exist in sunflower genome as well, Gentzbittel et al. (1998) designed degenerate primers and found R-genes in two tightly linked families. These resistance gene analogues (RGA) were than cloned and sequenced (Bouzidi et al., 2002). As a result, full-length RGA sequence was obtained and specific PCR primers that amplify 13 markers were created. These markers covered a genetic distance of about $3 \mathrm{cM}$ around the $\mathrm{Pl}_{6}$ locus, and gave a better insight into complexity of this locus. The utility of the markers created by Bouzidi et al. (2002) was verified by Panković et al. (2004). Subsequently, a codominant marker that completely co-segregates with $\mathrm{Pl}_{6}$ gene and can be used for MAS was developed (Panković et al., 2007). Two SSR markers, ORS 166 and ORS 1043, were also located within the HaRGC1 cluster (Slabaugh et al., 2003). These markers co-segregated with $\mathrm{Pl}_{6}$ (Panković et al. 2007), however later research suggested that the CAPS marker is probably in closer vicinity to $\mathrm{Pl}_{6}$ than the microsatellite markers (Imerovski et al., 2011c).

Several resistance gene candidates were also mapped on LG 8 and 13, and a smaller NBS-LRR-encoding clusters were mapped on linkage groups 1, 4, 9, and 15. Based on the sequences of two RGAs, 14 STS markers were developed within the $\mathrm{Pl}_{5} / \mathrm{Pl}_{8}$ locus (Radwan et al., 2003; 2004). Opposed to TIR-NBS-LRR that characterize $\mathrm{Pl}_{6}$ gene, RGA mostly linked to $\mathrm{Pl}_{5} / \mathrm{Pl}_{8}$ cluster are non-TIR-NBS-LRR (Radwan et al., 2003; 2004; Dimitrijević et al., 2011).

Bachlava et al. (2011) identified RGC markers tightly linked to $\mathrm{Pl}_{8}$ and $\mathrm{Pl}_{14}$. They investigated the genetic relatedness of linkage groups 1 and 13 RGCs with respect to the 783 NBS-LRR-encoding RGCs of sunflower, and laid the groundwork for positional cloning of $\mathrm{Pl}_{8}$ and $\mathrm{Pl}_{14}$. Dussle et al. (2004) mapped $\mathrm{Pl}_{\text {arg }}$ in the telomeric region of LG 1 , and found closely linked SSR markers that are useful for molecular assisted selection (Imerovski et al. 2011a). Wieckhorst et al. (2010) 
identified three NBS-LRR class resistance gene candidates (RGC151, RGC52a and RGC52b), and provided a groundwork for map-based cloning of this resistance locus.

\section{Conclusions and future prospects}

Even though a big step has been made towards understanding the complex interaction of the pathogen and sunflower, as well as the mechanisms of sunflower resistance, a number of questions have still remained unanswered. One of the problems that need to be addressed is the classification of pathogen races. It would be of a great significance if a unique molecular method for pathotype identification would be proposed. With the use of molecular markers, race composition in different sunflower cultivating regions could be determined with a higher accuracy. Additionally, tracking of the pathogen population dynamics, i.e., new race occurrence, would become possible.

A great number of authors have contributed to better understanding of the mechanisms involved in downy mildew resistance. The development of biotechnology resulted in molecular markers for detecting $P l$ genes, and provided means for marker assisted section (MAS).

Candidate resistance genes that have been proposed until now need to be confirmed in the future. Genes that were denoted differently and were introduced from the same resistance source need to be compared to exclude the possibility that they are the same one. To avoid confusion, a unique nomenclature should be used for denoting gens.

In order to keep up with the occurrence of new pathogen races, novel sources of resistance genes and corresponding sequence specific molecular markers need to be found. Mechanisms of quantitative resistance should be examined in more detail, and genes that are involved in the unspecific defence mechanism identified. Finally, a set of molecular markers that could be used for tracking QTL should be proposed. Marker assisted selection could in this way be used not only for detecting major but also for minor genes, and would bring us a step closer to achieving sustainable resistance to Plasmopara halstedii.

\section{ACKNOWLEDGEMENTS}

This work was supported by Ministry of Education and Science, Republic of Serbia, project TR 31025. 


\section{REFERENCES}

Aćimović, M., 1998. Bolesti suncokreta. Naučni institut za ratarstvo i povrtarstvo. Srbija. Novi Sad. Pp. 1-734.

Aegerter, B.J., Nuñez, J.J., Davis, R.M., 2003. Environmental factors effecting rose downy mildew and development of a forecasting model for a nursery production system. Plant Dis. 87(6): 732-738.

Bachlava, E., Radwan, O.E., Abratti, G., Tang, S., Gao, W., Heesacker, A.F., Bazzalo, M.E., Zambelli, A., Leon, A.J., Knapp, S.J., 2011 . Downy mildew $\left(P l_{8}\right.$ and $\left.P l_{14}\right)$ and rust $\left(R_{A d v}\right)$ resistance genes reside in close proximity to tandemly duplicated clusters of non-TIR-like NBS-LRR-encoding genes on sunflower chromosomes 1 and 13. Theor. Appl. Genet. 122(6): 1211-1221.

Bert, P.F., De Labrouhe, D.T., Philippon, J., Mouzeyar, S., Jouan, I., Nicolas, P., Vear, F., 2001. Identification of a second linkage group carrying genes controlling resistance to downy mildew (Plasmopara halstedii) in sunflower (Helianthus annuus L.). Theor. Appl. Genet. 103(6-7): 992-997.

Bertero de Romano, A., Romano, C., Bulos, M., Altieri, E., Sala, C., 2010. A new gene for resistance to downy mildew in sunflower. Proc. $8^{\text {th }}$ European Sunflower Biotechnology Conference, Antalya, Turkey. Pp. 141-146.

Bouzidi, M.F., Badaoui, S., Cambon, F., Vear, F., De Labrouhe, D.T., Nicolas, P., Mouzeyar, S., 2002. Molecular analysis of a major locus for resistance to downy mildew in sunflower with specific PCR-based markers. Theor. Appl. Genet. 104(4): 592-600.

Delmotte, F., Giresse, X., Richard-Cervera, S., M’Baya, J., Vear, F., Tourvieille, J., Walaser, P., de Labrouhe, D.T., 2008. Single nucleotide polymorphisms reveal multiple introductions into France of Plasmopara the plant pathogen causing sunflower downy mildew. Infect. Genet. Evol. 8(5): 534-540.

Dimitrijević, A., Imerovski, I., Miladinović, D., Jocić, S., Miklič, V., 2011. Use of molecular markers in identification of non-TIR-NBS-LRR RGA linked to downy mildew resistance locus Pl5/Pl8 in sunflower (Helianthus annuus L.). Proc. $19^{\text {th }}$ Symposium of the Serbian Plant Physiology Society, Banja Vrujci, pp. 80.

Dussle, C.M., Hahn, V., Knapp, S.J., Bauer, E., 2004. $P l_{\text {arg }}$ from Helianthus argophyllus is unlinked to other known downy mildew resistance genes in sunflower. Theor. Appl. Genet. 109(5): 1083-1086.

Gedil, M.A., Slabaugh, M.B., Berry, S., Johnson, R., Michelmore, R., Miller, J., Gulya, T., Knapp, S.J., 2001. Candidate disease resistance genes in sunflower cloned using conserved nucleotide-binding site motifs: Genetic mapping and linkage to the downy mildew resistance gene $\mathrm{Pl}_{1}$. Genome 44(2): 205-212.

Gentzbittel, L., Mouzeyar, S., Badaoui, S., Vear, F., Tourvieille de Labrouhe, D., Nicolas, P., 1998. Cloning of molecular markers for disease resistance in sunflower Helianthus annuus L. ISA Symposium III Sunflower Downy Mildew, Fargo, North Dakota, USA. Pp. 94-102.

Genzbittel, L., Vear, F., Zhang, Y.X., Berville, A., Nicolas, P., 1995. Development of a consensus linkage RFLP map of cultivated sunflower (H. annuus L.). Theor. Appl. Genet. 90(7-8): 1079-1086.

Giresse, X., de Labrouhe, D.T., Richard-Cervera, S., 2007. Twelve polymorphic expressed sequence tags-derived markers for Plasmopara halstedii, the causal agent of sunflower downy mildew. Mol. Ecol. Notes 7(6): 1363-1365.

Gisi, U., 2002. Chemical control of downy mildews. In: Spencer-Phillips P.T.N., Gisi, U., Lebeda. A. (eds.), Advances in downy mildew research. Kluwer Academic Publishers.

Gisi, U., Sierotzki, H., 2008. Fungicide modes of action and resistance in downy mildews. In: Lebeda, A,, Spencer-Philipps, P.T.N., Cooke, B.M. (eds.), The Downy Mildews-Genetics, Molecular Biology and Control, Springer.

Gulya, T.J., 2007. Distribution of Plasmopara halstedii races from sunflower around the world. Advances in Downy Mildew Research, Palacky University and JOLA Publishers 3: 121134.

Gulya, T.J., Sackston, W.E., Viranyi, F., Maširević, S., Rashid, K.Y., 1991. New races of the sunflower downy mildew pathogen (Plasmopara halstedii) in Europe and North and South America. J. Phytopathol. 132(4): 303-311.

Herbette, S., Lenne, C., de Labrouhe, D.T., Drevet, J.R., Roeckel-Drevet, P., 2003. Transcripts of sunflower antioxidant scavangers of the SOD and GPX families accumulate differen- 
tially in response to downy mildew infection, phytohormones, reactive oxygen species, nitric oxyde, protein kinase and phosphatase. Physiol. Plant 119(3): 418-428.

Imerovski, I., Dimitrijević, A., Miladinović, D., Jocić, S., Dedić, B., Miklič, V., 201 la. Detekcija prisustva gena $P l_{\text {arg }}$ u suncokretu pomoću SSR markera. Zbornik abstrakata IV Simpozijum Sekcije za oplemenjivanje organizama Društva genetičara Srbije, Kladovo, pp. 114.

Imerovski, I., Dimitrijević, A., Miladinović, D., Jocić, S., Miklič, V., 201 b. Unošenje gena otpornosti prema plamenjači u suncokret i njihova detekcija molekularnim metodama. Zbornik radova, 52. Savetovanje: Proizvodnja i prerada uljarica, Herceg Novi, Crna Gora, pp. 103-108.

Imerovski, I., Dimitrijević, A., Miladinović, D., Jocić, S., Miklič, V., 2011 c. Detection of resistance of sunflower to downy mildew using sequence specific DNA marker. Proc. $19^{\text {th }}$ Symposium of the Serbian Plant Physiology Society, Banja Vrujci, pp. 67.

Jocić, S., Saftić-Panković, D., Hladni, N., Cvejić, S., Radeka, I., Miklič, V., 2009. Oplemenjivanje na otpornost prema plamenjači suncokreta. Zbornik radova Instituta za ratarstvo i povrtarstvo 46(1): 181-188.

Jocić, S., Cvejić, S., Hladni, N., Miladinović, D., Miklič, V., 2010. Development of sunflower genotypes resistant to downy mildew. Helia 33(53): 173-180.

Kaya, Y., Jocić, S., Miladinović, D., 2012. Molecular Breeding. In: Technological Innovations in Major World Oil Crops: Breeding ( $1^{\text {st }}$ Edition, Vol. 1), Gupta, S.K. (ed.), Springer, Dordrecht, Heidelberg, London, New York. Pp. 85-129.

Korosi, K., Ban, K., Barna, B., Viranyi, F., 2011. Biochemical and Molecular Changes in Downy Mildew-infected Sunflower Triggered by Resistance Inducers. J. Phytopathol. 159(7-8): 471-478.

Lačok, N., 2008. Zdrav suncokret-garancija za dobijanje ulja visokog kvaliteta. Zbornik radova 49. Savetovanja: Proizvodnja i prerada uljarica, Herceg Novi, Crna Gora. Pp. 45-51.

Lai, Z., Livingstone, K., Zou, Y., Church, S.A., Knapp, S.J., Andrews, J., Rieseberg, L.H., 2005. Identification and mapping of SNPs from ESTs in sunflower. Theor. Appl. Genet. $111(8): 1532-1544$.

Liu, Z., Gulya, T.J., Seiler, G.J., Vick, B.A., Jan, C., 2011. Genetic mapping of HA-R4 identified the downy mildew resistance gene to races 300, 770, and 734. Sunflower Research Forum, Fargo.

Maširević, S., 1998. Dynamics of occurrence of downy mildew races (Plasmopara halstedii) on sunflower in Yugoslavia. Proc. $2^{\text {nd }}$ Balkan Symposium of field crops, Novi Sad, Serbia. Pp. 387-390.

Mauch-Mani, B., 2002. Host resistance to downy mildew diseases. In: Spencer-Phillips, P.T.N., Gisi, U., Lebeda, A. (eds.), Advances in downy mildew research. Kluwer Academic Publishers.

Meliala, C., Vear, F., Tourvieille de Labrouhe, D., 2000. Relation between date of infection of sunflower downy mildew (Plasmopara halstedii) and symptoms development. Helia 23(32): 35-44.

Mihaljčević, M., Muntañola-Cvetković, M., Petrov, M., 1982. Further studies on the sunflower disease caused by Diaporthe (Phomopsis) helianthi and possibilities of breeding for resistance. Proc. $10^{\text {th }}$ International Sunflower Conference, Surfers Paradise, Australia. Pp. 157-159.

Miladinović, D., Marjanović-Jeromela, A., Jocić, S., Hladni, N., Imerovski, I., Dimitrijević, A., Vuković, N., 2011. Biotehnološke metode u NS programima oplemenjivanja suncokreta i uljane repice. Zbornik radova 52. Savetovanja: Proizvodnja i prerada uljarica, Herceg Novi, Crna Gora. Pp. 109-114.

Miller, J.F., Gulya, T.J., 1988. Registration of 6 downy mildew resistant sunflower germplasm lines. Crop Sci. 28: 1040-1041.

Miller, J.F., Gulya, T.J., 1991. Inheritance of resistance to race 4 of downy mildew derived from interspecific crosses in sunflower. Crop Sci. 31: 40-43.

Mouzeyar, S., Tourvieille de Labrouhe, D., Vear, F., 1993. Histopathological studies of resistance of sunflower (Helianthus annuus L.) to downy mildew (Plasmopara halstedii). J. Phytopathol. 139: 289-297.

Mouzeyar, S., Tourvieille de Labrouhe, D., Vear, F., 1994. Effect of host-race combination on resistance of sunflower (Helianthus annuus L.) to downy mildew (Plasmopara halstedii). J. Phytopathol. 141(3): 249-258.

Mulpuri, S., Liu, Z., Feng, J., Gulya, T., Jan, C-C., 2009. Inheritance and molecular mapping of a downy mildew resistance gene, $\mathrm{Pl}_{13}$ in cultivated sunflower (Helianthus annuus L.). 
Theor Appl Genet. 119(5):795-803. Epub 2009 Jun 26. doi:10.1007/s00122-0000901089-z.

Panković, D., Jocić, S., Lačok, N., Sakač, Z., Škorić, D., 2004. The use of PCR-based markers in the evaluation of resistance to downy mildew in NS-breeding material. Helia 27(40): 149-158.

Panković, D., Radovanović, N., Jocić, S., Satović, Z., Škorić, D., 2007. Development of codominant amplified polymorphic sequence markers for resistance of sunflower to downy mildew race 730. Plant Breed. 126(4): 440-444.

Pérez-Vich, B., Velasco, L., Fernández-Martínez, J.M., 2004. QTL mapping of resistance to races $\mathrm{E}$ and $\mathrm{F}$ of broomrape (Orobanche cumana Wallr.) in sunflower. Parasitic Plant Management in Sustainable Agriculture Meeting on Breeding for Orobanche Resistance in Sunflower, Bucharest, Romania, pp. 6 .

Rachid Al-Chaarani, G., Roustaee, A., Gentzbittel, L., Mokrani, L., Barrault, G., DechampGuillaume, G., Sarrafi, A., 2002. A QTL analysis of sunflower partial resistance to downy mildew (Plasmopara halstedii) and black stem (Phoma macdonaldii) by the use of recombinant inbred lines (RILs). Theor. Appl. Genet. 104(2-3): 490-496.

Radwan, O., Bouzidi, M.F., Nicolas, P., Mouzeyar, S., 2004. Development of PCR markers for $\mathrm{Pl}_{5} / \mathrm{Pl}_{8}$ locus for resisance to Plasmopara halstedii in sunflower, Helianthus annuus L. from complete CC-NBS-LRR sequence. Theor. Appl. Genet. 109(1): 176-185.

Radwan, O., Bouzidi, M.F., Vear, F., Philippon, J., Tourvieille de Labrouh, D., Nicolas, P., Mouzeyar, S., 2003. Identification of non-TIR-NBS-LRR markers linked to $\mathrm{Pl}_{5} / \mathrm{Pl}_{8}$ locus for resistance to downy mildew in sunflower. Theor. Appl. Genet. 106(8): 1438-1446.

Radwan, O., Gandhi, S., Heesacker, A., Whitaker, B., Taylor, C., Ploick, A., Kesseli, R., Kozik, A., Michelmore, R.W., Knapp, S.J., 2008. Genetic diversity and genomic distribution of homologes encoding NBS-LRR disease resistance proteins in sunflower. Mol. Genet. Genomics. 280: 111-125.

Radwan, O., Mouzeyar, S., Venisse, J.S., Nicolas, P., Bouzidi, M.F., 2005. Resistance of sunflower to the biotrophic oomycete Plasmopara halstedii is associated with a delayed hypersensitive response within the hypocotyl. J. Exp. Bot. 56(420): 2683-2693.

Roeckel-Drevet, P., Tourvieille, J., Gulya, T.J., Charmet, G., Nicolas, P., Tourvieille de Labrouhe, D., 2003. Molecular variability of sunflower downy mildew, Plasmopara halstedii, from different continents. Can. J. Microbiol. 49(8): 492-502.

Sackstone, W.E., 1990. A proposed international system for designing races of Plasmopara halstedii. Plant Dis. 74: 721-724.

Sakr, N., 2010. Studies on pathogenicity in Plasmopara halstedii (sunflower downy mildew). Int. J. Life. Sci. 4: 48-59.

Sakr, N., Ducher, M., Tourvieille, J., Walser, P., Vear, F., Tourvieille de Labrouhe, D., 2009. A method to measure aggressiveness of Plasmopara halstedii (Sunflower DownyMildew). J. Phytopathol. 157 (2): 133-136.

Seiler, G.J, Christie, B.R., Choo, T.M., 1991. Registration of 13 downy mildew tolerant interspecific sunflower germplasm lines derived from wild annual species. Crop Sci. 31 : 1714-1716.

Slabaugh, M.B., Yu, J.K., Tang, S., Heesacker, A., Hu, X., Lu, G., Han, F., Bidney, D., Knapp, S.J., 2003. Haplotyping and mapping a large cluster of resistance gene candidates in sunflower using multilocus intron fragment length polymorphisms. Plant Biotech. J. 1: 167-185.

Spring, O., Bachofer, M., Thines, M., Riethmüller, A., Göker, M., Oberwinkler, F., 2006. Intraspecific relationship of Plasmopara halstedii isolates differing in pathogenicity and geographic origin based on ITS sequence data. Eur. J. Plant Pathol. 114(3): 309-315.

Spring, O., Thines, M., 2004. On the necessity of new characters for classification and systematics of biotrophic Peronosporomycetes. Planta 219: 910-914.

Škorić, D., 1985. Sunflower breeding for resistance to Diaporthe/Phomopsis helianthi Munt.Cvet. et al. Helia 8: 21-24.

Tang, S., Yu, J.K., Slabaugh, M.B., Shintani, D.K., Knapp, S.J., 2002. Simple sequence repeat map of the sunflower genome. Theor. Appl. Genet. 105(8): 1124-1136.

Tourvieille de Labrouhe, D., Mouzeyar, S., Lafon, S., Regnaylt, Y., 1991. Evolution des races de mildiou (Plasmopara halstedii) sur tournesol en France. Proc. $3^{\text {rd }}$ International Confference on Plant Diseas, Bordeaux, France. Pp. 777-784.

Tourvieille de Labrouhe, D., Pilorge, E., Nicolas, P., Vear, F., 2000. Le mildiou du tournesol. CETIOM- INRA, Versailles, France. 
Tourvieille de Labrouhe, D., Serre, F., Walser, P., Roche, S., Vear, F., 2008a. Quantitative resistance to downy mildew (Plasmopara halstedii) in sunflower (Helianthus annuus). Euphytica 164 (2): 433-444.

Tourvieille de Labrouhe, D., Walser, P., Serre, F., Roche, S., Vear, F., 2008b. Relations between spring rainfall and infection of sunflower by Plasmopara halstedii (downy mildew). In: Velasco, L. (ed.), Proc. $17^{\text {th }}$ International Sunflower Conference, Cordoba, Spain 1: 97 102.

Vasić, D., Marinković, R., Miladinović, F., Jocić, S., Škorić, D., 2004. Gene actions affecting sunflower resistance to Sclerotinia sclerotiorum measured by sclerotia infections of roots, stems and capitula. Proc. $16^{\text {th }}$ International Sunflower Conference, Fargo, North Dakota, USA. Pp. 603-608.

Vear, F., Serre, F., Jouan-Dufournel, I., Bert, P.F., Roche, S., Walser, P., Tourvieille de Labrouhe, D., Vincourt, P., 2008. Inheritance of quantitative resistance to downy mildew (Plasmopara halstedii) in sunflower (Helianthus annuus L.). Euphytica 64(2): 561-570.

Vear, F.D., 2010. Classic genetics and Breeding. In: Genetics, Genomics and Breeding of Sunflower. Jinguo, H, Seiler, G, Kole, C. (ed.), Science Publishers, Enfield, New Hampshire. Pp. 51-78.

Viranyi, F., Spring, O., 2011. Advances in sunflower downy mildew research. Eur. J. Plant Pathol. 129: 207-220.

Voglmayr, H., Constantinescu, O., 2008. Revision and reclassification of three Plasmopara species based on morphological and molecular phylogenetic data. Mycol. Res. 112(5): 487-501.

Wehtje, G., Zimmer, D.E., 1978. Downy mildew of sunflower: biology of systemic infection and the nature of resistance. Phytopathology 68: 1568-1571.

Wieckhorst, S., Bachlava, E., Dussle, C.M., Tang, S., Gao, W., Saski, C., Knapp, S.J., Schön, C.C., Hahn, V., Bauer, E., 2010. Fine mapping of the sunflower resistance locus $P l_{\text {arg }}$ introduced from wild specied Helianthus argophyllus. Theor. Appl. Genet. 121(8): 16331644.

Yu, J.K., Mangor, J., Thompson, L., Edwards, K.J., Slabaugh, M.B., Knapp, S.J., 2002. Allelic diversity of simple sequence repeats among elite inbred lines of cultivated sunflower. Genome 45(4): 652-660.

Yu, J.K., Tang, S., Slabaugh, M.B., Heesacker, A., Cole, G., Herring, M., Soper, J., Han, F., Chu, W., Webb, D.M., Thompson, L., Edwards, K.J., Berry, S., Leon, A.J., Grondona, M., Olungu, C., Maes, N., Knapp, S.J., 2003. Towards a saturated molecular genetic linkage map for cultivated sunflower. Crop Sci. 43(1): 367-387.

Zimmer, D.E., Fick, G.M., 1974. Some diseases of sunflower in the United States - their occurrence, biology and control. Proc. $6^{\text {th }}$ International Sunflower Conference, Bucharest, Romania. Pp. 673-680. 